\title{
Il linguaggio grafico di Hugh Ferriss tra chiaroscuro e illustrazione 3D
}

\author{
Cristian Farinella \\ Lorena Greco
}

\section{Abstract}

A seguito del concorso indetto e promosso da D2 Conference e Droquis, la comunità internazionale di 3D architectural visualizer ha riproposto, mediante immagini realizzate al computer (CGI), una rilettura del patrimonio grafico e progettuale degli edifici rappresentati in The Metropolis of Tomorrow da Hugh Ferriss. Il presente contributo espone il lavoro del primo classificato nella competizione, con una ricognizione sull'impiego delle tecniche di chiaroscuro digitale e del linguaggio grafico adottato, oltre che un'analisi sulle influenze dirette del lavoro di Ferriss nella cinematografia e nel racconto a fumetti.

Parole chiave

Hugh Ferriss, linguaggi grafici, chiaroscuro, illustrazione, fumetto.

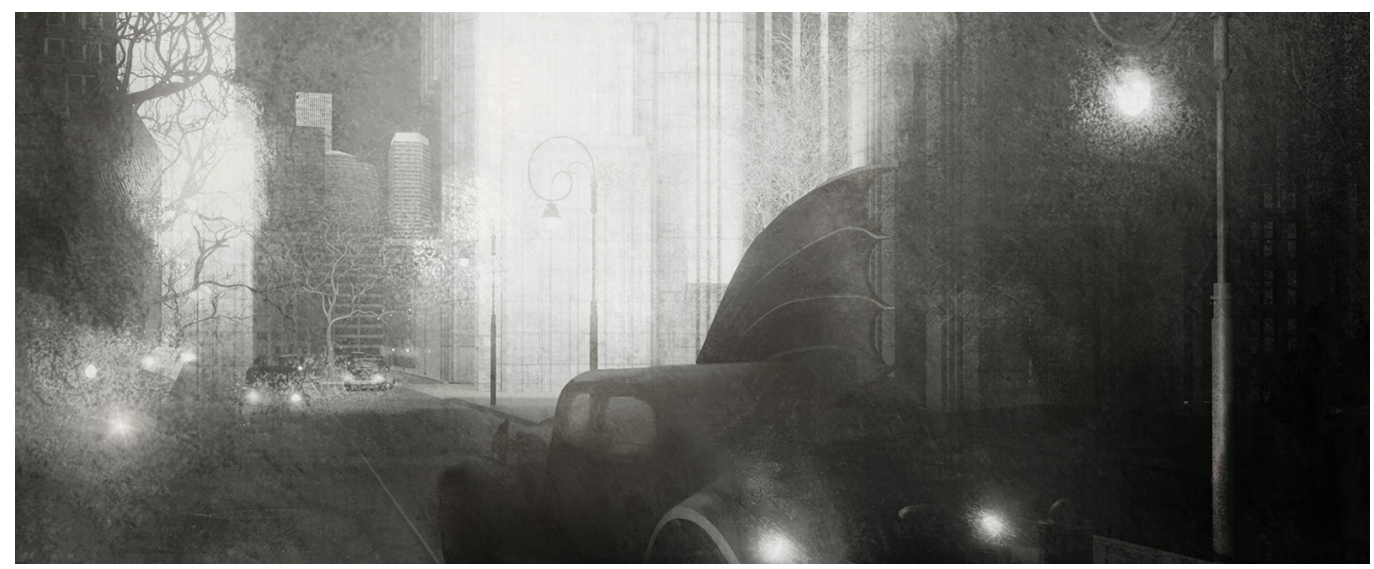




\section{La figura di Hugh Ferriss}

II concorso lanciato a Ottobre 2020 dalla D2 Conference [I] di Vienna, in collaborazione con l'artista Mike Golden (alias Droquis), ha avuto come tema le architetture e il linguaggio grafico di Hugh Ferriss, architetto e progettista visionario tra i più influenti d'America negli anni Venti eTrenta. Ė sua la pubblicazione di Metropolis of Tomorros (1929) che lo ha posto al centro del dibattito sugli edifici alti a New York, influenzando la percezione che il pubblico aveva delle nuove metropoli in formazione lungo il continente americano. Nel 1916, la zoning law di New York si propose di regolarizzare lo sviluppo della morfologia urbana e le metodologie di occupazione del suolo di Manhattan, per imporre, tra l'altro, la caratteristica forma a setback che si può ritrovare negli edifici successivi. La nuova legge fu occasione di numerose commesse per Ferriss e, all'interno della pubblicazione del 1929, i rendering monocromi (a carboncino) rappresentano in maniera eloquente i progetti di edifici e grattacieli su cui il delineator ha avuto modo di lavorare. The Metropolis of Tomorrow è diventato così un riferimento visivo per le successive generazioni di architetti, cineasti, e fumettisti, come nel caso di Bob Kane e della sua Gotham City, ispirata all'immaginario proposto da Ferriss [2]. II libro racchiude 59 tavole ed è strutturato in tre parti: nelle Cities of Today sono presentati i progetti di grattacieli esistenti ritenuti esemplari; nei Projected Trends sono rappresentate le tendenze progettuali del momento; An Imaginary Metropolis, infine, riguarda le trasformazioni di una città ideale attraverso i progetti d'invenzione ideati dello stesso Ferriss. II successo e la fama dei rendering architettonici - grazie alle pubblicazioni a mezzo stampa su quotidiani e riviste - hanno reso Ferriss uno dei più influenti disegnatori del periodo, tanto che nel 1929 è sempre a cura del delineator americano la voce Rendering Architectural nella quattordicesima edizione dell'Enciclopedia Britannica [3]. Il testo è accompagnato da numerose immagini con rimandi storici e contemporanei (da Piranesi a Cass Gilbert) e nella definizione enciclopedica sono posti in evidenza i principali obiettivi del rendering. Questi si riferiscono all'abilità, da parte del delineator, di interpretare le idee e il lavoro degli architetti, come pure di prefigurare, mediante il rendering, nuove tipologie di progetto - per gli sviluppi futuri della città - e di manifestare l'influenza dell'architettura sui valori della società contemporanea.

Fig. I. Striscia a fumetti, vincitrice de D2 Challenge No.l. realizzata da Atelier Crilo. L'inclusione del cavaliere oscuro, e di un tipico brano di Gotham City, è un esplicito riferimento alle ambientazioni ideate da Bob Kane e Bill Finger direttane e Bill Finger, direttamente ispirate dalle visioni Ferriss degli anni Trenta.
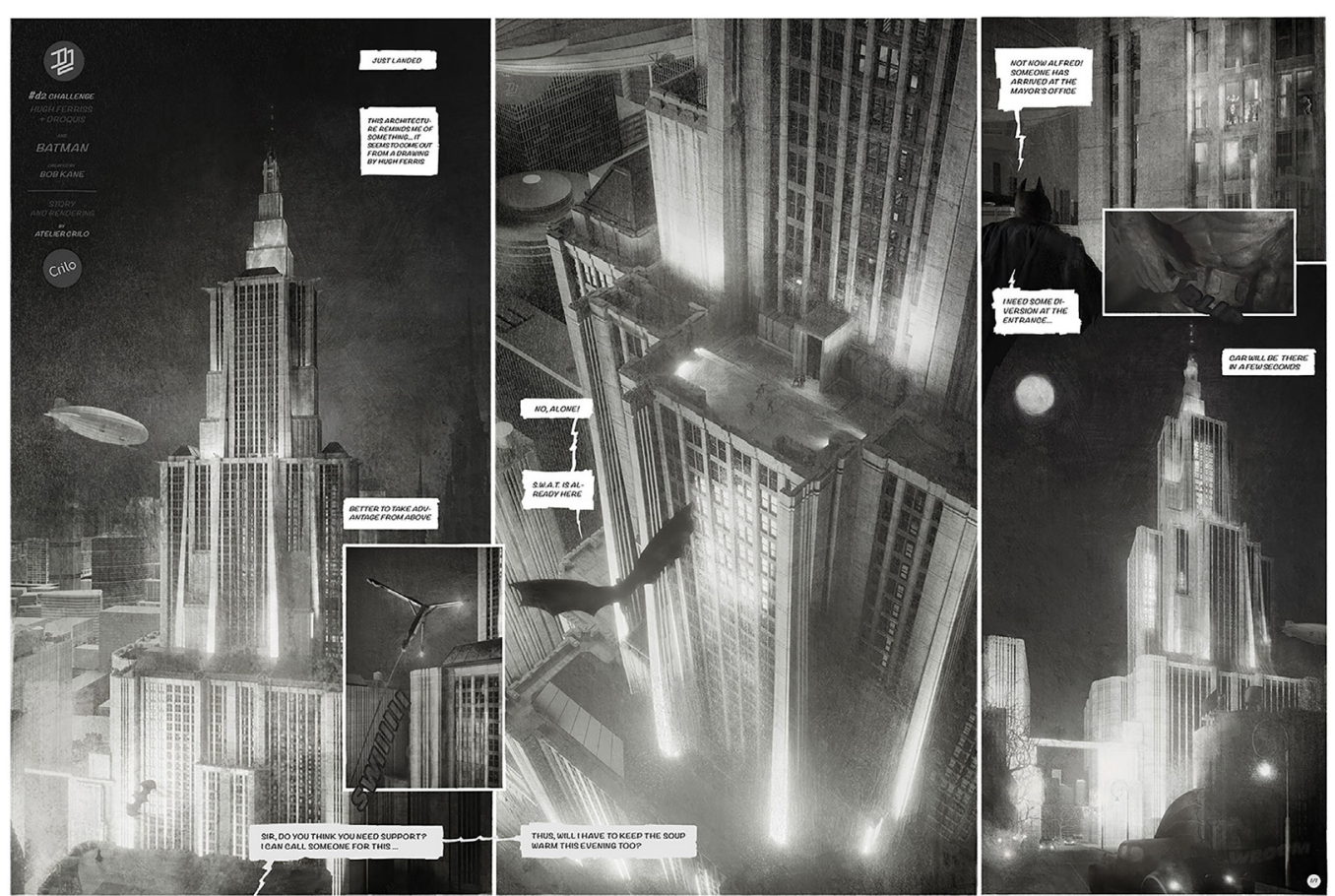


\section{La competizione D2 Challenge}

Una sfida impegnativa e complessa quella posta dalla D2 Conference e da Mike Golden, di interpretare attraverso il rendering le architetture e il linguaggio di Hugh Ferriss. Alla competizione hanno partecipato circa duecento specialisti della visualizzazione architettonica, impiegati nelle più note compagnie di archviz. Per citarne alcuni: Lisa Della Dora (art director del Master MADI e visualizer presso lo studio Bloomimages), Andrea Cogo (senior $3 d$ artist, Bloomimages), Nicolò Garonzi (senior 3d artist Brick Visual), Angelo Cicatiello e Andrea Gallo (archviz artists presso Luxigon, Parigi), Vittorio Bonapace (art/creative director), Lucia Frascerra (senior visualisation artist presso Secchi Smith e precedentemente Cityscape Digital e Dbox), inoltre, Nuno Silva (nu.ma) e numerosi altri [4].Tra i primi tre classificati:Vito Summa, Erica Ruiz, e il vincitore Atelier Crilo (studio fo

ndato e diretto da chi scrive) con una sequenza narrativa incentrata su Ferriss e il fumetto (fig. I). Il materiale di concorso, messo a disposizione dei partecipanti, consisteva in una serie di modelli 3D riferiti a partiture architettoniche tra cui lesene, corpi scala, soluzioni d'angolo e parti di facciata, da assemblare in maniera libera per ricostruire una scenografia tanto iconica quanto prossima ai disegni del prospettivista americano. L'operazione ha spinto molti partecipanti a conoscere e studiare con attenzione il patrimonio grafico e progettuale contenuto in The Metropolis ofTomorrow, tanto da sublimare, in molti casi, le architetture di riferimento. II video introduttivo del membro di giuria e promotore del contest Mike Golden
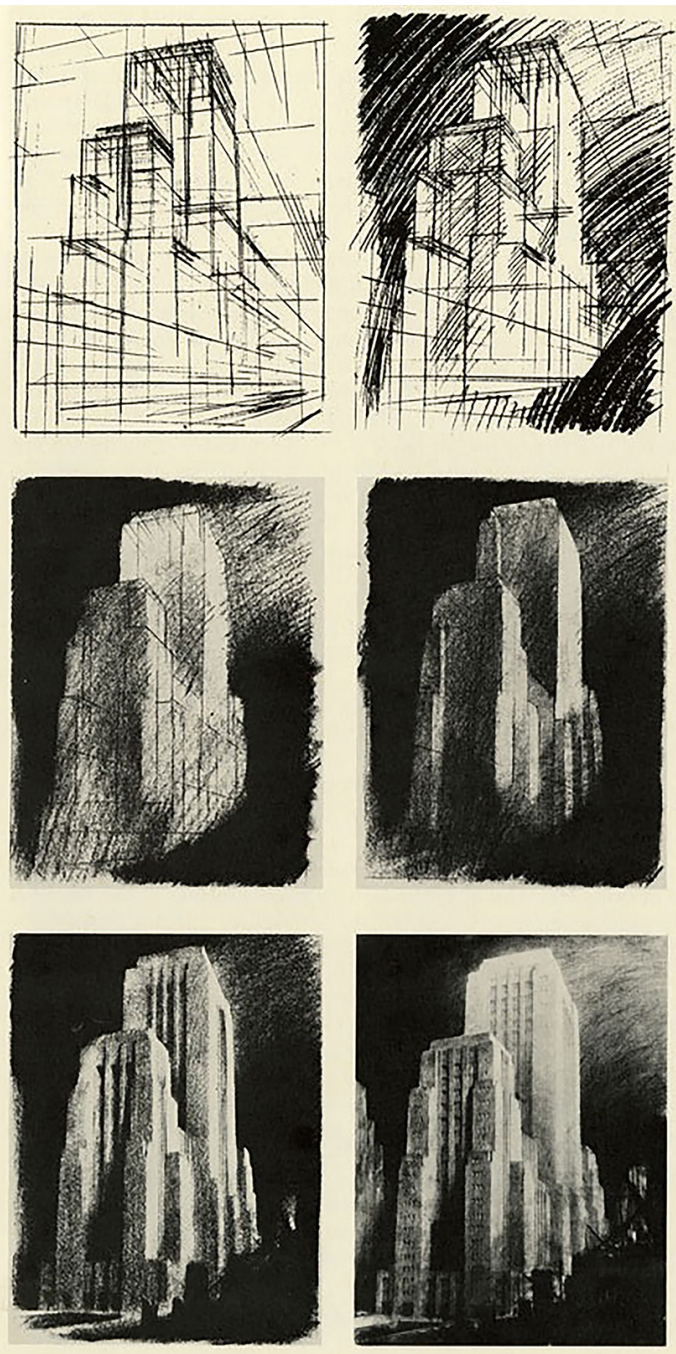
(noto come Droquis), mostra un'esplorazione libera dei volumi primigeni e delle tecniche di illuminazione congegnate da Ferriss, mediante rapidi schizzi digitali e sessioni di rendering interattivo. La video introduzione al concorso, disponibile su youtube [5], ha rappresentato una fonte di notevole ispirazione per i partecipanti, e le realizzazioni presentate dallo stesso Golden sono di ineccepibile livello sia tecnico che artistico.

Anche lo sviluppo visivo del progetto vincitore ha avuto inizio da un'attenta analisi del lavoro e delle opere visive direttamente ispirate a Ferriss. È risultato di notevole interesse rintracciare le influenze nella cinematografia, nel fumetto, e nel connubio della trasposizione filmica di storie a fumetti. Alle architetture ideate da Ferriss si sono ispirati art director come Erich Kettelhut, per creare le ambientazioni e i modelli di scena per la futuristica Metropolis (1927) di Fritz Lang. Nel racconto illustrato The Reign of the Superman. A short story by Jerry Siegel (1933), il disegnatore Joe Shuster richiama nella città d'invenzione Metropolis le svariate architetture disegnate da Ferriss e diffuse a mezzo stampa da riviste ad ampia tiratura quali: the Century Magazine, the Christian Science Monitor, Harper's Magazine, Vanity Fair. Perfino il Daily Planet, sede del giornale dove Clark Kent svolge il lavoro da reporter, si ispira alla tipica conformazione a setback degli edifici rappresentati in The Metropolis of Tomorrow. Lo stesso edificio viene più volte rivisitato dalla filmografia recente del supereroe, per continuare a ispirarsi ai disegni originari di Ferriss. In Superman Returns (2006) di Bryan Singer, ad esempio, il production designer Hendrix Dyas si riferisce in maniera esplicita all'originario Daily Planet presente nelle prime storie a fumetti. Inoltre, tra gli appassionati dell'universo DC (Detective Comics) sono note le scenografie ideate da Anton Furst del Batman (1989) diretto da Tim Burton. Le ambientazioni, i disegni al tratto, assieme al design dei veicoli, valsero allo scenografo inglese un Academy Award per la direzione artistica e diedero slancio

Fig. 3. Processo di creazione dell'immagine al computer seguito da Atelier Crilo. In alto a sinistra: clay-render, output con texture (di fianco). In basso a sinistra: canal ID per selezioni, postproduzione e colorazion produzlone e colorazione digitale (over painting) A destra: illustrazione progetto, sommatoria
delle fasi precedenti.
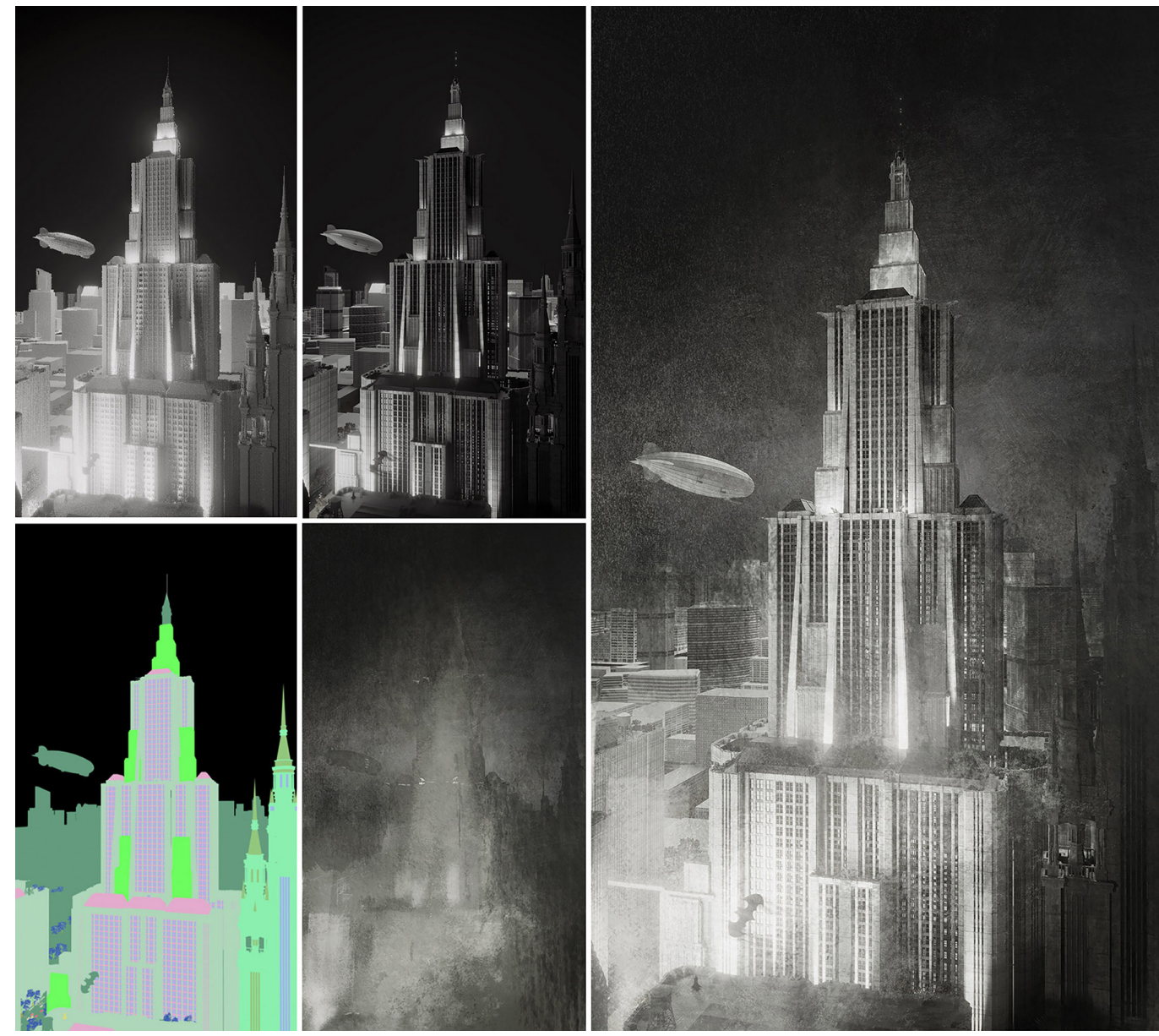
anche a una breve esperienza nelle storie a fumetti. La miniserie dedicata al cavaliere oscuro, intitolata Destroyer (199I), venne pubblicata alcuni mesi dopo del tragico suicidio di Furst, e rappresenta l'ultima opera disegnata dall'autore inglese. Nelle pagine dell'albo su Batman si rintracciano tutti gli elementi stilistici che collegano l'universo di Furst ai disegni di Ferriss, per l'impiego delle tinte oscure e neogotiche delle sue ambientazioni, nonché della vicinanza e dei rimandi all'incisione e al più celebre intrico di derivazione piranesiana.

\section{Sul linguaggio grafico}

A sostegno della lettura e interpretazione dei disegni di Hugh Ferriss, vengono in supporto le parole di Franco Purini che, con l'illustratore americano, ha avuto in comune il ruolo di prospettivista. L'architetto romano ha, infatti, cominciato a lavorare alla fine degli anni Sessanta nello studio di Maurizio Sacripanti [6], proprio per la capacità di prefigurare nello spazio architetture e spazialità complesse; si ricordi a titolo di esempio la nota prospettiva del progetto del Padiglione di Osaka. Ed è in uno studio intitolato II disegno nell'architettura italiana che Purini, con l'obiettivo di individuare le relazioni che caratterizzano il complesso rapporto tra l'architettura e la sua rappresentazione, descrive il disegno come una sorta di "palinsesto infinito", il quale - in maniera più o meno esplicita - convoglia "elementi narrativi, suggestioni iconiche, diversioni, corredi simbolici e allegorici" [Purini 20 I I , p. 3 I]. L'autore sottolinea come il ruolo della rappresentazione del progetto architettonico vada ben oltre

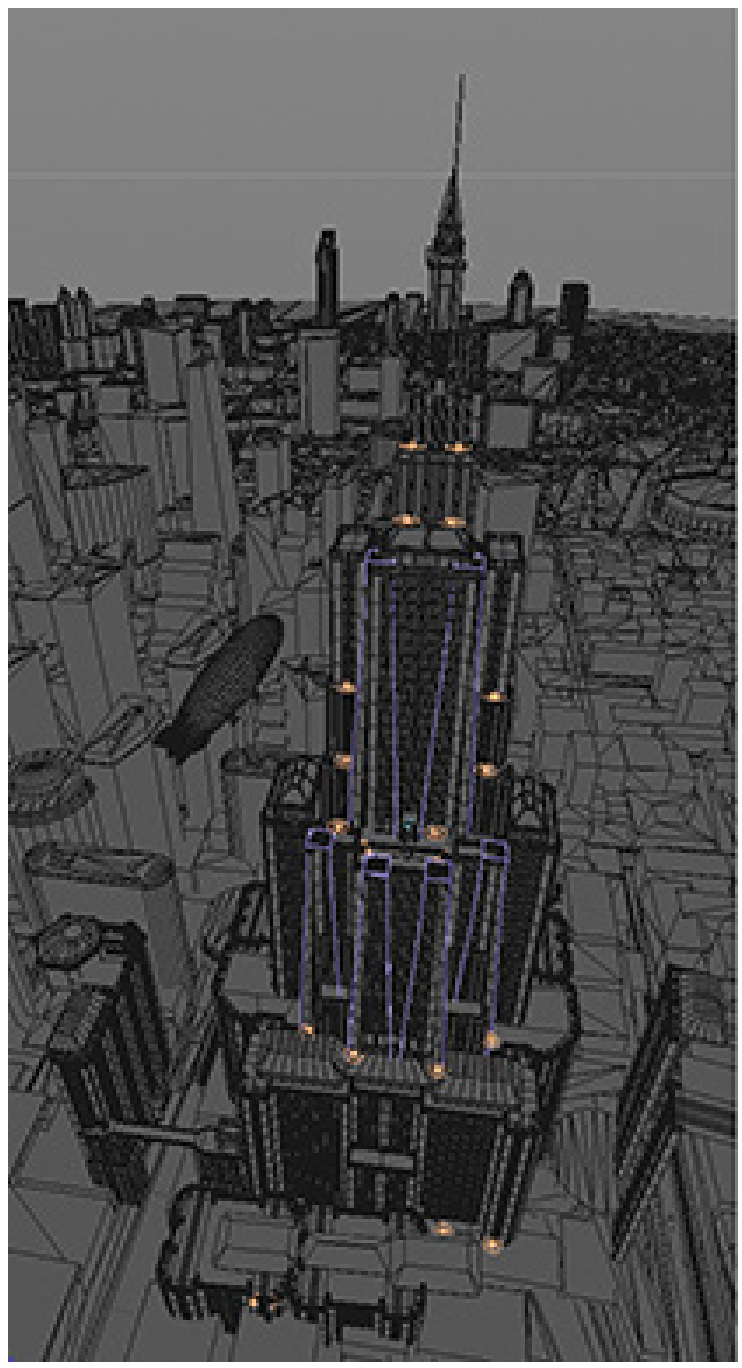


la trascrizione di una idea e della sua comunicazione; essa stratifica memorie, ragionamenti, pentimenti, per lasciare traccia anche delle indecisioni, degli arresti e delle riprese nell'iter progettuale. In questo senso, la rappresentazione, secondo lo studioso romano, raccoglie in sé almeno tre tipologie di contenuto: in primo luogo è la "trascrizione di una idea", dunque un sistema di segni in grado di esplicitare un pensiero; il secondo contenuto è riferito alla "comunicazione" dell'idea stessa, si tratta quindi di elaborazioni grafiche capaci di riferirsi a degli interlocutori differenti dall'autore stesso; infine, il disegno incorpora "memoria", owvero conserva traccia di pentimenti e sottolineature tali da poter andare a ritroso nelle fasi che hanno caratterizzato l'iter progettuale. In altre parole, il disegno non è mai univoco e Francesco Cellini, in un saggio intitolato Sul talento e sul gesto, mette in luce un ulteriore aspetto riguardante la tecnica. Riferendosi al disegno e, più in generale, all'opera d'arte, Cellini osserva come:"molto spesso [...] ci si soffermi ad analizzare solo alcune delle sue qualità, quelle comunemente ritenute più alte e significative e, quindi degne di essere discusse e trasmesse: si parla e si legge cioè di struttura generale, dello spazio o della forma, di composizione, di soggetti (se ci sono), di contenuto [... . Resta però un imbarazzato silenzio su tutto l'insieme delle caratteristiche più minute e perciò basilari di un'opera: su quella particolare stesura o qualità materica delle pennellate, sulla conformazione di quei segni o tratti, [...] su quel modo di muovere quello specifico pennello, o matita, o sgorbia ecc." [Cellini 2006, p. 93].

Cellini pone l'attenzione sul linguaggio e sullo stile grafico, per specificare la differenza che intercorre tra il tratto ossessivo, ripetitivo, e chirurgicamente preciso, di Franco Purini e il tratto robusto, nonché sintetico, di Alessandro Anselmi. Si tratta di differenze soltanto in parte casuali o imputabili al talento di ognuno, bensì, profondamente connesse alle scelte compiute dai disegnatori, agli strumenti adottati, e conseguenza del risultato espressivo che ogni progettista vuole raggiungere.

Fig. 5. Schizzi preparatori in carboncino e grafite per la successiva fase d pittura digitale e postproduzione dell'output di rendering.

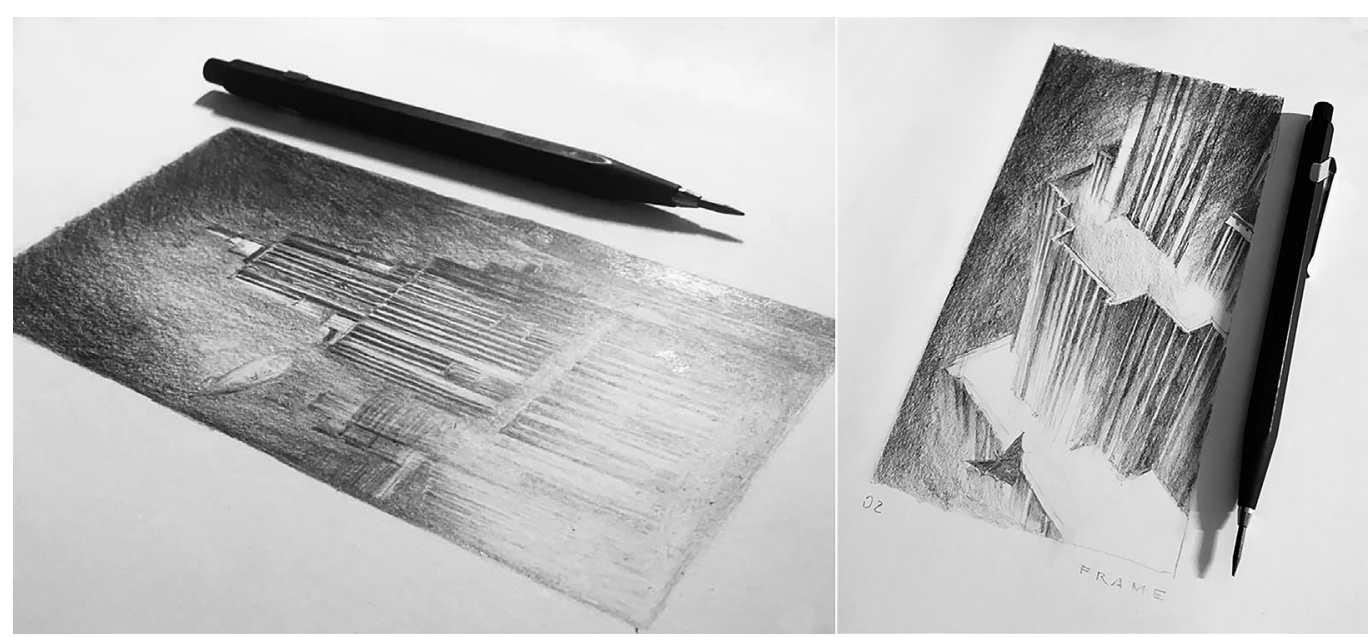

\section{La reiterazione delle tecniche di Hugh Ferriss tramite il chiaroscuro digitale}

Seguendo i ragionamenti di Francesco Cellini, i disegni di Hugh Ferriss, oltre ai contenuti di tipo progettuale che esplorano lo sviluppo verticale della città, registrano una molteplicità di aspetti relativi alla tecnica. In primo luogo di natura pratica, legati all'utilizzo del carboncino e della fusaggine per il tratteggio dei volumi, che esplicita e definisce una metodologia di lavoro per la rappresentazione degli edifici. Ferriss rende manifeste le fasi che vanno dalla costruzione della prospettiva fino alla fase di chiaroscuro e di definizione dei dettagli (fig. 2). In maniera analoga, anche le immagini prodotte al computer, per D2 Challenge, sono state elaborate per mezzo di fasi distinte (fig. 3). La sfida, da parte di chi scrive, è stata quella di raggiungere un contenuto espressivo del tutto in linea con la matericità degli strumenti 
Fig. 6. Le trame (texture) impiegate per post-produrre loutput di render. I tre tipi di pennelli digitali sono stati creati in Adobe Photoshop per corrispondere a tre livelli di luminosità e variazione tonale. II primo pennello (A) simula la grafite, per le trame più chiare dell'immagine; il secondo (B) è impiegati peritoni intermed peritoni intermed eper dara grana terzo pennello (C), viene terzo pennello (C), viene impiegato per riprodurre I tratti a carboncino e la fusaggine (parti scure), ed il gesso (in bianco). tradizionali del disegno, quale ad esempio il carboncino, impiegato da Ferriss. Procedendo per ordine, e confrontando gli elaborati di Ferriss con gli analoghi sviluppi digitali (figg. 2, 3), il primo passo è legato alla costruzione della prospettiva; il punto di vista viene individuato tramite un disegno a tratto nella versione a mano e tramite clay rendering in quella digitale. L'ambientazione notturna e l'illuminazione scenografica, dal basso verso l'alto, è stata riprodotta tramite il contributo del 'cielo fisico' color antracite e delle 'luci d'accento' alla base delle lesene di facciata (fig. 4). II progetto di illuminazione della scena è stato indagato tramite rapidi schizzi in carboncino e grafite (fig. 5), che hanno guidato la fase di pittura digitale e post-produzione dell'output di rendering. In seguito all'esportazione del canale ID dei materiali, attraverso cui si possono rintracciare e selezionare tutte le superfici, sono stati creati tre tipi di pennelli digitali corrispondenti a tre livelli di luminosità e variazione tonale (fig. 6). II primo a simulare la grafite (fig. 6a), quindi utilizzato per realizzare delle trame superficiali sulle parti più chiare dell'immagine; il secondo (fig. 6b) per aggettivare il tono intermedio dell'elaborato; infine, il terzo pennello (fig. 6c), impiegato per riprodurre sia i tratti a carboncino e la fusaggine (in nero), che il gesso (in bianco), con l'obiettivo di contrastare e dare profondità all'immagine.

II grado di casualità ottenuto dalla combinazione di pressione e inclinazione dei pennelli sul rendering di base (fig. 7a), e la stratificazione dei segni in pittura digitale (fig. 7b), hanno consentito di dissimulare la natura omogenea e intangibile delle immagini realizzate in computer grafica, e di ricondurre la rappresentazione verso una sintesi materica e imperfetta (fig. 7c), tipica del disegno a mano e del deposito di grafite sul foglio di carta.

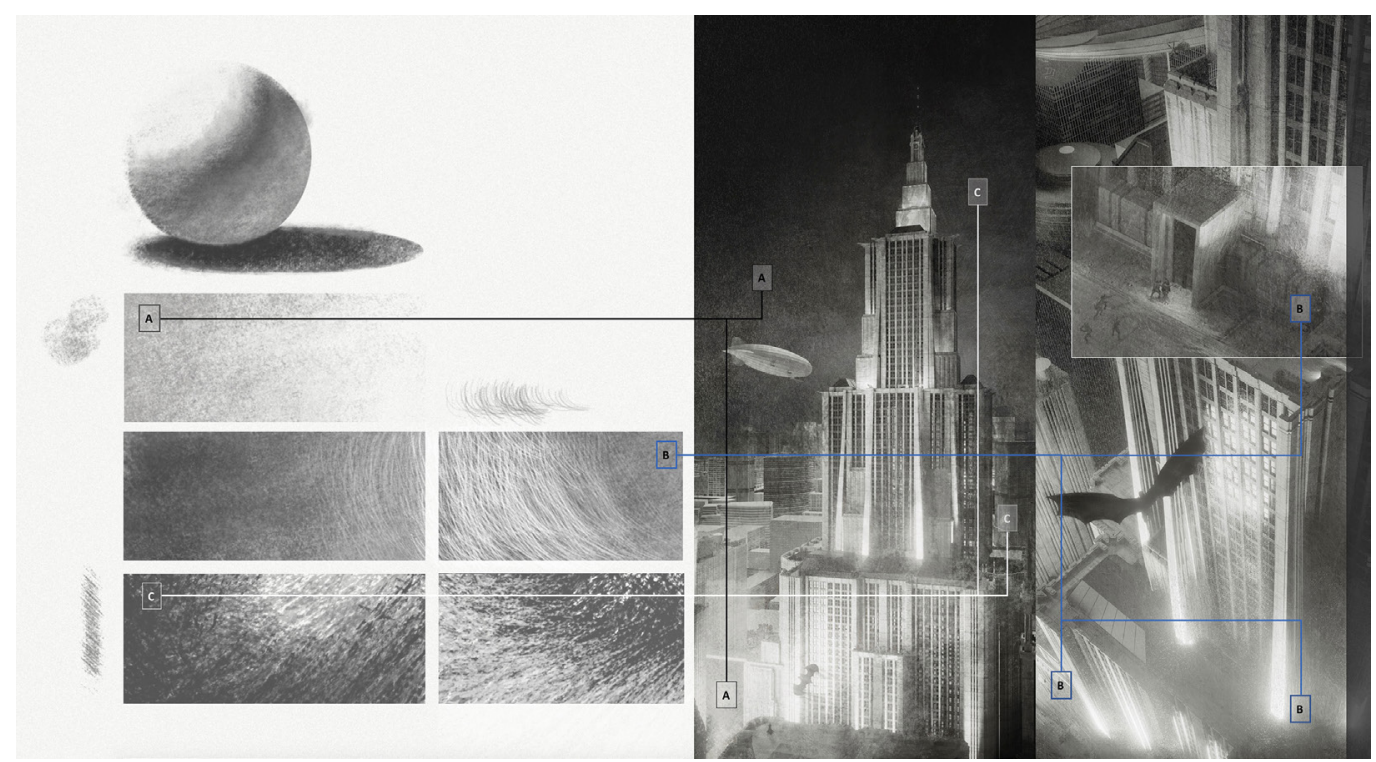

\section{Conclusioni}

La competizione indetta dalla D2 Conference ha dato modo ai visualizer d'architettura, e alla comunità internazionale di artisti digitali, di conoscere e reinterpretare il lavoro di Hugh Ferriss, celebre delineator americano e progettista visionario. Nelle visualizzazioni presentate dai partecipanti emerge come non esista un confine tra lo sviluppo progettuale e quello visivo. Mike Golden, ad esempio, esplora il progetto architettonico nelle sue spazialità mediante sessioni di rendering interattivo, nelle quali studia il comportamento della luce, dei materiali e, di conseguenza, sceglie di modificare la morfologia attraverso un processo iterativo. Inoltre, il linguaggio grafico adottato dagli autori del presente testo e del caso studio presentato è incentrato sulla resa espressiva e materica delle tecniche tradizionali del disegno (come 
il carboncino e la fusaggine), per rievocare la memoria esperienziale del contatto tra le pennellate e le superfici. Per tornare al già citato Cellini, una rappresentazione viene caratterizzata dalla conformazione dei segni e dei tratti, oltre che dagli aspetti compositivi, dallo spazio e dalla forma del progetto.

Infine, in maniera comune, tutti i partecipanti del concorso hanno indagato lo stato dell'arte, le referenze e gli stimoli provenienti dal cinema, e adottato un linguaggio visivo coerente con il soggetto rappresentato. Questa metodologia di lavoro, è un principio valido per la rappresentazione prospettica degli spazi, sia che tratti di chiaroscuro a mano, sia che si utilizzino le più recenti soluzioni di rendering oggi a disposizione. In quest'ottica, il lavoro dell'archviz artist, tramite le possibilità espressive della computer grafica, risulta sempre più determinante - e in continuità con il ruolo del prospettivista tradizionale - nel riscoprire e indagare sia le architetture del passato, quanto nel comunicare quelle di sviluppo recente.

Fig. 7. In successione da sinistra a destra: l'output di render, il lavoro di overpainting con i pennell digitali, l'unione dei due contributi precedenti nell'elaborato di sintesi.
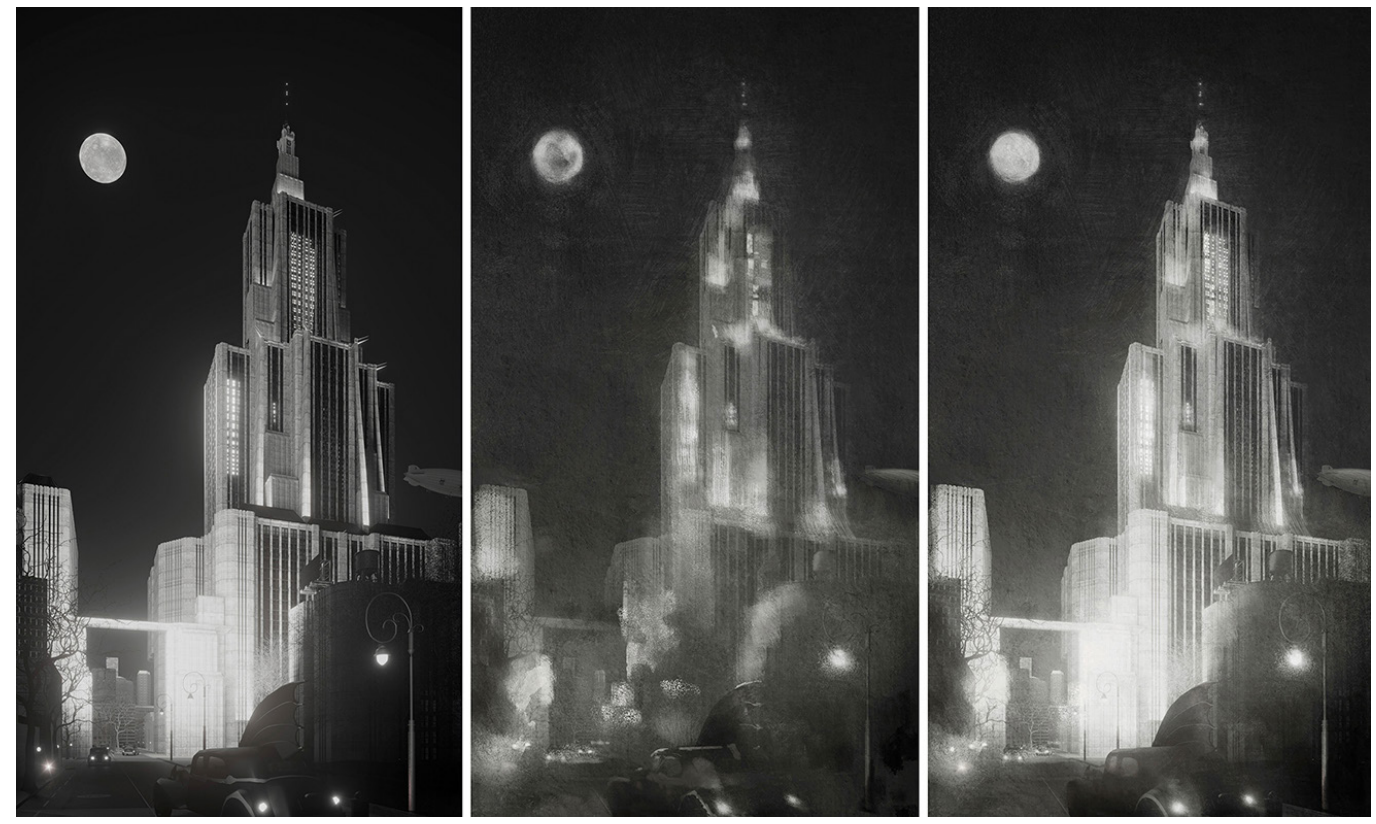

\section{Crediti}

Gli autori hanno lavorato nella piena condivisione del progetto in ogni sua fase. In particolare, Cristian Farinella si è occupato dei paragrafi dedicati alla figura di Hugh Ferriss e al D2 Challenge, mentre Lorena Greco ha indagato il paragrafo dedicato al linguaggio grafico e alla reiterazione delle tecniche di Hugh Ferriss tramite chiaroscuro digitale.

\section{Note}

[I] Conferenza annuale organizzata da BÜROWHAT e nello specifico dai co-fondatori: Jason Bergeron, Christian Kobierski e Fabio Palvelli. L'intento è quello di riunire a Vienna la comunità internazionale di archviz e di monitorare novità e tendenze in fatto di linguaggio nella comunicazione architettonica. La prima edizione risale al 20 I4; per approfondimenti si rimanda al sito d2 Conference in Vienna: <http://vienna.d2conferences.com> (consultato il I 5 febbario 202 I).

[2] Cfr. Biraghi, Ferlenga 2012, p. 878.

[3] Cfr. Ferriss H. 1929, pp. |46- 149.

[4] Gli elaborati dei primi 25 classificati sono disponibili al seguente link: https://vienna.d2conferences.com/d2challenge/ hugh-ferriss-droquis/hugh-ferriss-droquis-top-25/> (consultato il I5 febbario 202I).

[5] II video di lancio del D2 challenge è consultabile a questo link: $<$ https://www.youtube.com/watch?v=r)pl5_lilRU> (consultato il 15 febbario 202I).

[6] Ci si riferisce al racconto fatto da Franco Purini, consultabile al sito: <https://www.youtube.com/watch?v=NoX7t7asAsA>. (consultato il I 5 febbario 202I). 


\section{Riferimenti bibliografici}

Biraghi M., Ferlenga A. (2012). Architettura del Novecento, vol. I. Torino: Einaudi.

Cellini F. (2006). Sul talento e sul gesto. In R. M. Strollo (a cura di). Disegno e conoscenza. Contributi per la storia e l'architettura. Roma: Aracne, pp. 93-104.

Ferriss H. (1929). Rendering, Architectural. In The Encyclopaedia Britannica, I $4^{\text {th }}$ edition. London and New York: University of Chicago Press.

Purini F. (20 I I). II disegno nell'architettura italiana. In M. Petreschi. Diario per segni. Roma: «L'Erma» di Bretschneider, pp. I75- I 83.

\section{Sitografia}

Atelier Crilo (2020). Architectural illustration. <http://www.ateliercrilo.com/architectural-illustration-drawing-watercolors-digitalpainting $>$ (consultato il I 5 febbraio 202I)

D2 Conferenze (2020). D2 Vienna 2020. <https://vienna.d2conferences.com> (consultato il I 5 febbraio 202 I).

D2 Vienna (2020). Hugh Ferriss + Droquis, D2 Challenge No. I. <https://vienna.d2conferences.com/d2challenge/hugh-ferriss-droquis/> (consultato il I 5 febbraio 2021).

D2Vienna (2020). Top 25. <https://vienna.d2conferences.com/d2challenge/hugh-ferriss-droquis/hugh-ferriss-droquis-top-25/> (consultato il I5 febbraio 2021).

Droquis (2020). How to make a Hugh Ferriss inspired image in 3D - D2 Render Challenge. <https://www.youtube.com/ watch?v=rjpl5_lilRU> (consultato il I 5 febbraio 202 I).

Golden M. Artstation - Droquis. <https://www.artstation.com/droquis> (consultato il I5 febbraio 202I).

Ferriss H. (1929). The Metropolis of Tomorrow. New York: Ives Washburn. Disponibile al link: <https://bibliodarq.files.wordpress. com/20 I7/06/ferriss-h-the-metropolis-of-tomorrow.pdf> (consultato il I5 febbraio 202I)

Purini F. (20 I5). Fondo Sacripanti |Testimonianze | Franco Purini. <https://www.youtube.com/watch?v=NoX7t7asAsA> (consultato il 15 febbraio 2021).

\section{Autori}

Cristian Farinella, Sapienza Università di Roma, cristian.farinella@uniroma l.it

Lorena Greco, Sapienza Università di Roma, lorena.greco@uniromal.it

Per citare questo capitolo: Farinella Cristian, Greco Lorena (2021). Il linguaggio grafico di Hugh Ferriss tra chiaroscuro e illustrazione 3D In A/The graphic language of Hugh Ferriss between chiaroscuro and 3D illustration. In Arena A., Arena M.. Mediati D. Raffa P. (a cura di). Connettere Un disegno per annodare e tessere Linguagoi Distanze Tecnologie Atti del $42^{\circ}$ Convegno Internazionale dei Docenti delle Discipline della Rappresentazione/ Connecting. Drawing to weaving relationship. Languages Distances Technologies. Proceedings of the $42^{\text {th }}$ International Conference of Representation Disciplines Teachers. Milano: FrancoAngeli, pp. 722-739. 


\title{
The Graphic Language of Hugh Ferriss between Chiaroscuro and 3D Illustration
}

\author{
Cristian Farinella \\ Lorena Greco
}

\section{Abstract}

Following the competition launched and promoted by D2 Conference and Droquis, 3D Architectural visualizer's international community has re-proposed, through computer-graphic imagery (CGI), a reinterpretation of the graphic language and buildings represented in The Metropolis of Tomorrow, a famous book by Hugh Ferriss. This contribution exhibits the work of the first classified in the competition, with a survey on the use of digital chiaroscuro techniques, the graphic language adopted and an analysis of the direct influences of Ferriss's work in cinematography and comic book stories.

\section{Keywords}

Hugh Ferriss, graphic languages, chiaroscuro, illustration, comics.

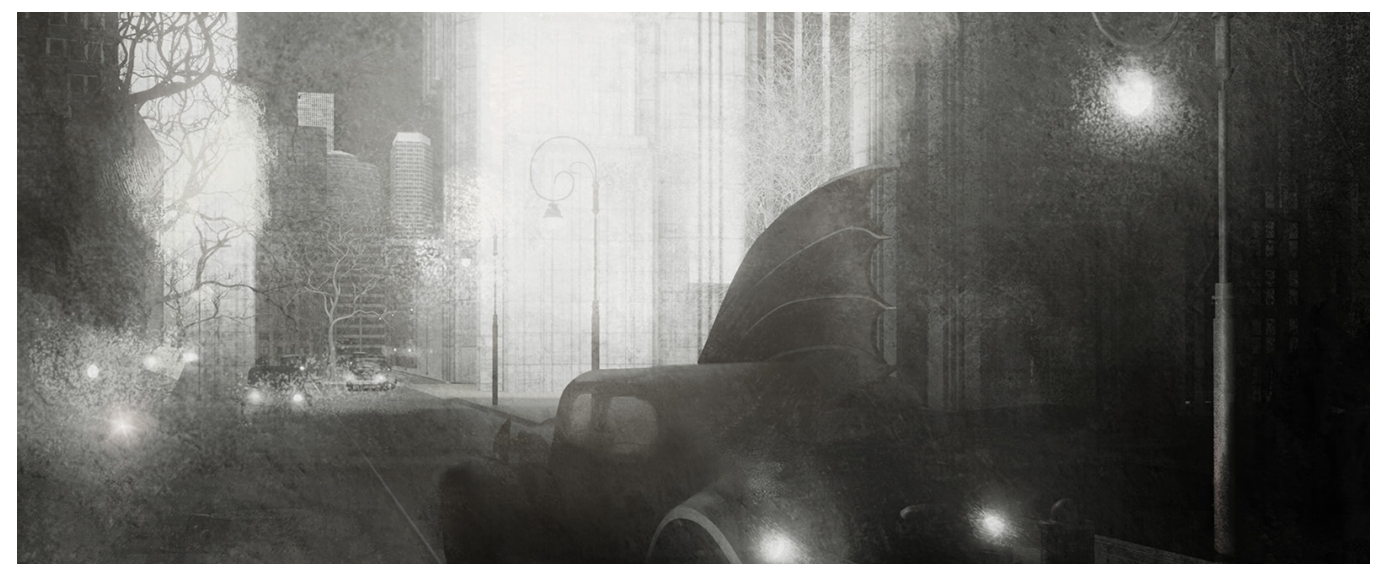




\section{Hugh Ferriss, the delineator}

The competition launched in October 2020 by the D2 Conference [I] in Vienna, in collaboration with the artist Mike Golden (alias Droquis), promoted as central theme the architecture and graphic language of Hugh Ferriss, one of the most influential architects and visionary designer in America during the twenties and thirties. His publication The Metropolis of Tomorrow (1929) placed him at the center of the debate on tall buildings in New York, influencing the public's perception of new metropolises forming along the American continent.

In 1916, the zoning law of New York set out to regularize the development of the urban morphology and the land occupation methodologies of Manhattan, to impose, among other things, the characteristic setback shape that can be found in subsequent buildings. The new law was the occasion of numerous orders for Ferriss and, within the 1929 publication, the monochrome renderings (in charcoal) eloquently represent the projects for buildings and skyscrapers on which the delineator had the opportunity to work.

The Metropolis of Tomorrow has thus become a visual reference for the following generations of architects, filmmakers, and cartoonists, as in the case of Bob Kane and his Gotham City, inspired by the imagery proposed by Ferriss [2]. The book contains 59 tables and is structured in three parts: in the Cities of Today, projects for existing skyscrapers considered exemplary are presented; the Projected Trends show the design trends of the moment; finally, An Imaginary Metropolis concerns the transformations of an ideal city through the inventive projects conceived by Ferriss himself. Thanks to the publications in newspapers and magazines, the success and fame of architectural renderings made Ferriss one of the most influential designers of the period.Thus, in 1929 the entry Rendering, Architectural in the fourteenth edition of the Encyclopaedia Britannica [3] includes the same American delineator. The text is accompanied by numerous images with historical and contemporary references (from Piranesi to Cass Gilbert), and the main objectives of the rendering are highlighted in the encyclopedic definition. These refer to the ability, on the part of the delineator, to interpret the ideas and work of architects, as well as to foreshadow, through rendering, new types of projects -for the future developments of the city-and to manifest the influence of architecture on the values of contemporary society.

Fig. I. Comic strip, winner of the D2 Challenge No. I, created by Atelier Crilo. The inclusion of the Dark Knight, and a typical Gotham City scene, is an explicit reference to the building environment designed by Bob Kane designed by Bob Kane and Bill Finger, directly inspired by Hugh Ferriss architectural visions of the 1930s.
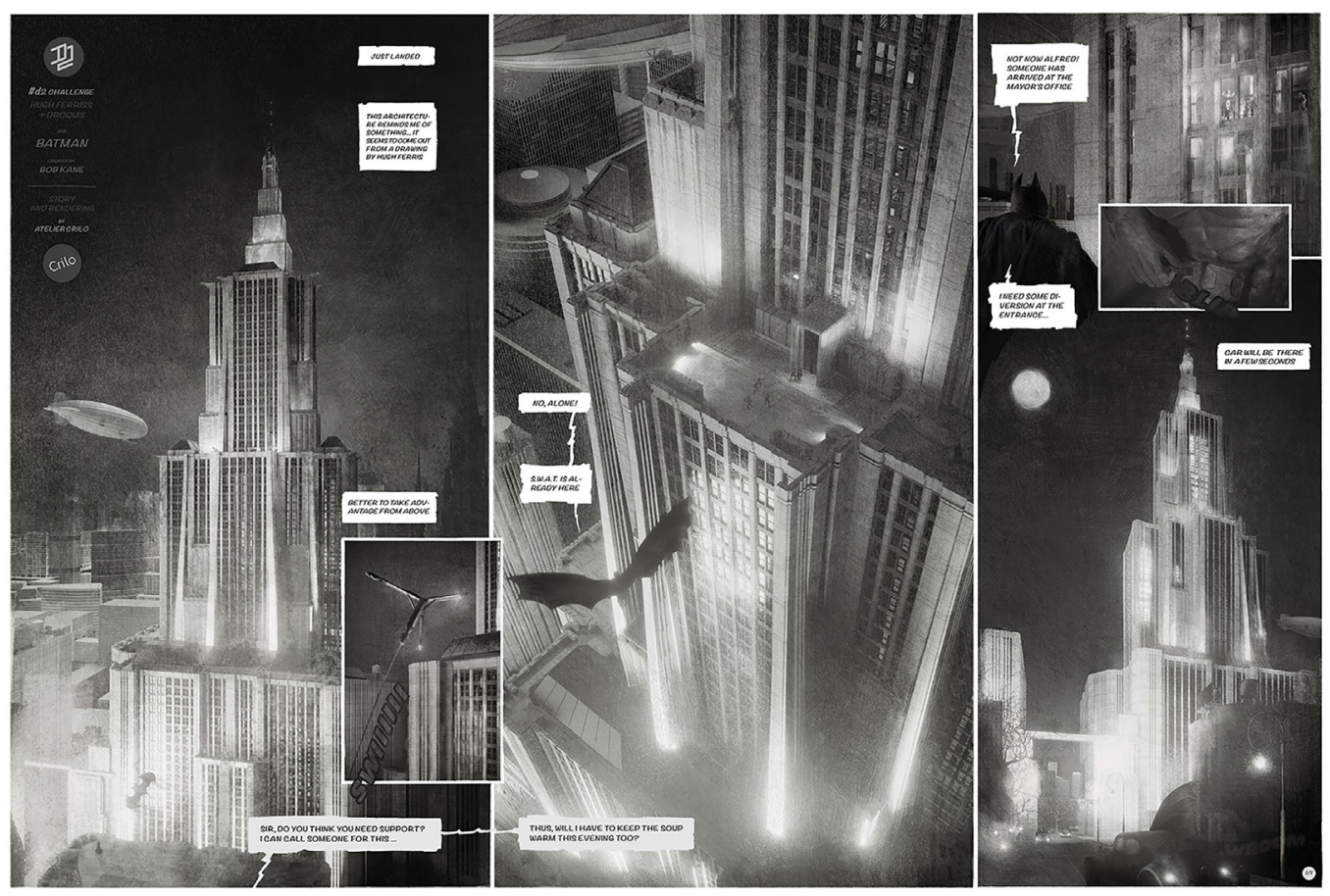


\section{The D2 challenge competition}

A demanding and complex challenge posed by the D2 Conference and by Mike Golden to interpret the architecture and language of Hugh Ferriss through rendering. About two hundred specialists of architectural visualization were attended by the competition, employed in the most famous archviz companies. To name a few: Lisa Della Dora (art director of the Master MADI and visualizer at Bloomimages studio), Andrea Cogo (senior 3d artist, Bloomimages), Nicolò Garonzi (senior 3d artist Brick Visual), Angelo Cicatiello and Andrea Gallo (archviz artists at Luxigon, Paris),Vittorio Bonapace (art and creative director for his own Ltd company), Lucia Frascerra (senior visualization artist at Secchi Smith and formerly Cityscape Digital and Dbox), in addition, Nuno Silva (nu.ma studio) and numerous others [4]. Among the first three classifieds:Vito Summa, Erica Ruiz, and the winner Atelier Crilo (studio founded and directed by the writer) with a narrative sequence focused on Ferriss and comics (fig. I). The competition material, made available to the participants, consisted of a series of 3D models referring to architectural parts, including pilasters, staircases, corner solutions, and portions of the façade. The aim was to assemble them freely and reconstruct a scenography as iconic as it is close to the designs of the American perspectivist. The operation inspired many participants to get to know and carefully study the graphic and design heritage contained in The Metropolis ofTomorrow, so much so that, in many cases, the initial reference architectures have been sublimated by their 'replicas'. The introductory video by jury member
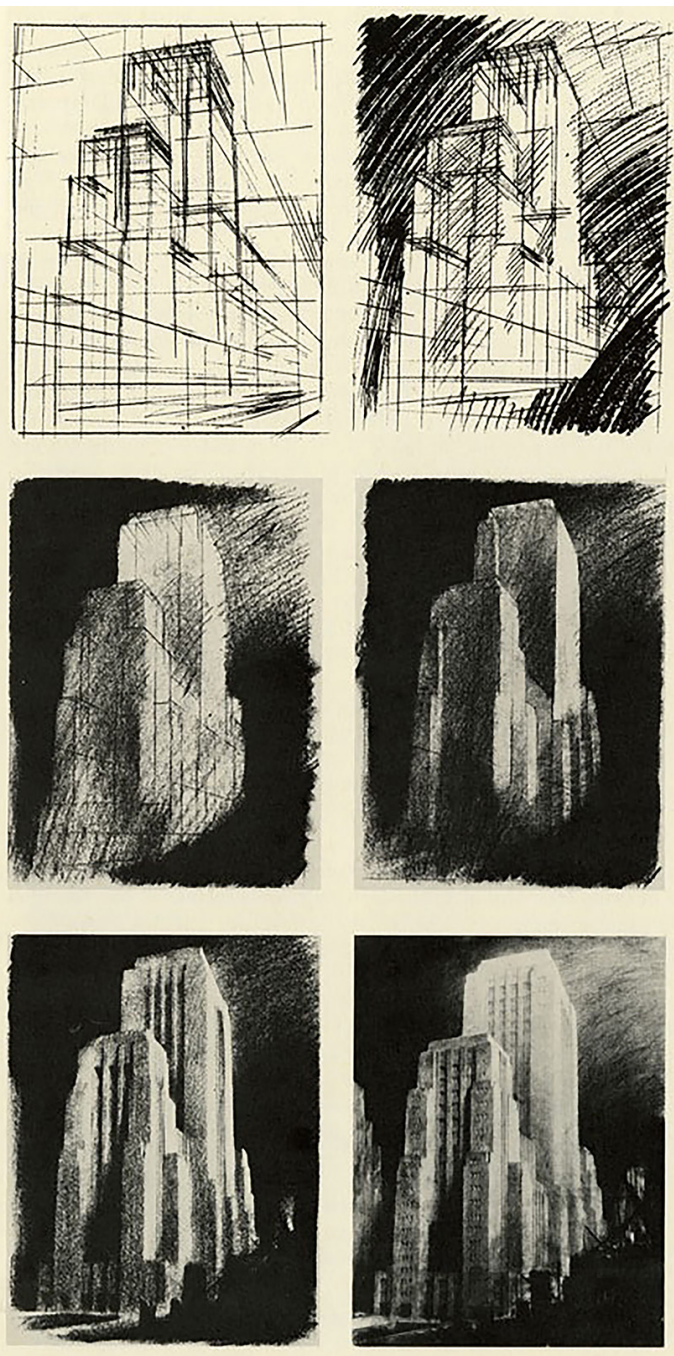
and contest promoter Mike Golden (known as Droquis) shows an exploration of Ferriss's primitive volumes and lighting techniques through rapid digital sketches and interactive rendering sessions. The video introduction to the competition, available on youtube [5], represented a source of considerable inspiration for the participants, and the creations presented by Golden himself are of impeccable technical and artistic level. The winning project's visual development also began with a careful analysis of the work and graphic works directly inspired by Ferriss. It was of considerable interest to trace the influences in cinematography, comics, and in the combination of the film transposition of comic stories. Ferriss's architecture inspired art directors such as Erich Kettelhut to create the settings and stage models for Fritz Lang's futuristic Metropolis (1927). In the illustrated story The Reign of the Superman. A short story by Jerry Siegel (1933), the designer Joe Shuster introduces the city of invention Metropolis that recalls the various architectures designed by Ferriss and disseminated in the magazines, widely read, such as: The Century Magazine, The Christian Science Monitor, Harper's Magazine, Vanity Fair. Even the Daily Planet, home of the newspaper where Clark Kent works as a reporter, is inspired by the typical setback conformation of the buildings represented in The Metropolis of Tomorrow. The recent superhero filmography repeatedly revisits the same building to continue to be inspired by Ferriss's original designs. In Bryan Singer's Superman Returns (2006), production designer Hendrix Dyas explicitly refers to the actual Daily Planet featured in the first comic stories. Besides, the DC (Detective Comics) fans know very well the scenographies designed by Anton Furst for Batman (1989), directed by Tim Burton. The movie environments, the drawings, together with the vehicles' design, earned the English scenographer an Academy Award for art direction and gave impetus to a brief experience in comic stories. The miniseries dedicated to the dark knight, entitled Destroyer (1991), was

Fig. 3. Computer image creation process followed by Atelier Crilo. Top left: clay-render, textured output (opposite) Bottom left: ID channel for selections post-production and digital coloring (over painting). coloring (over painting). Right: illustration of the project, summation of the previous phases.
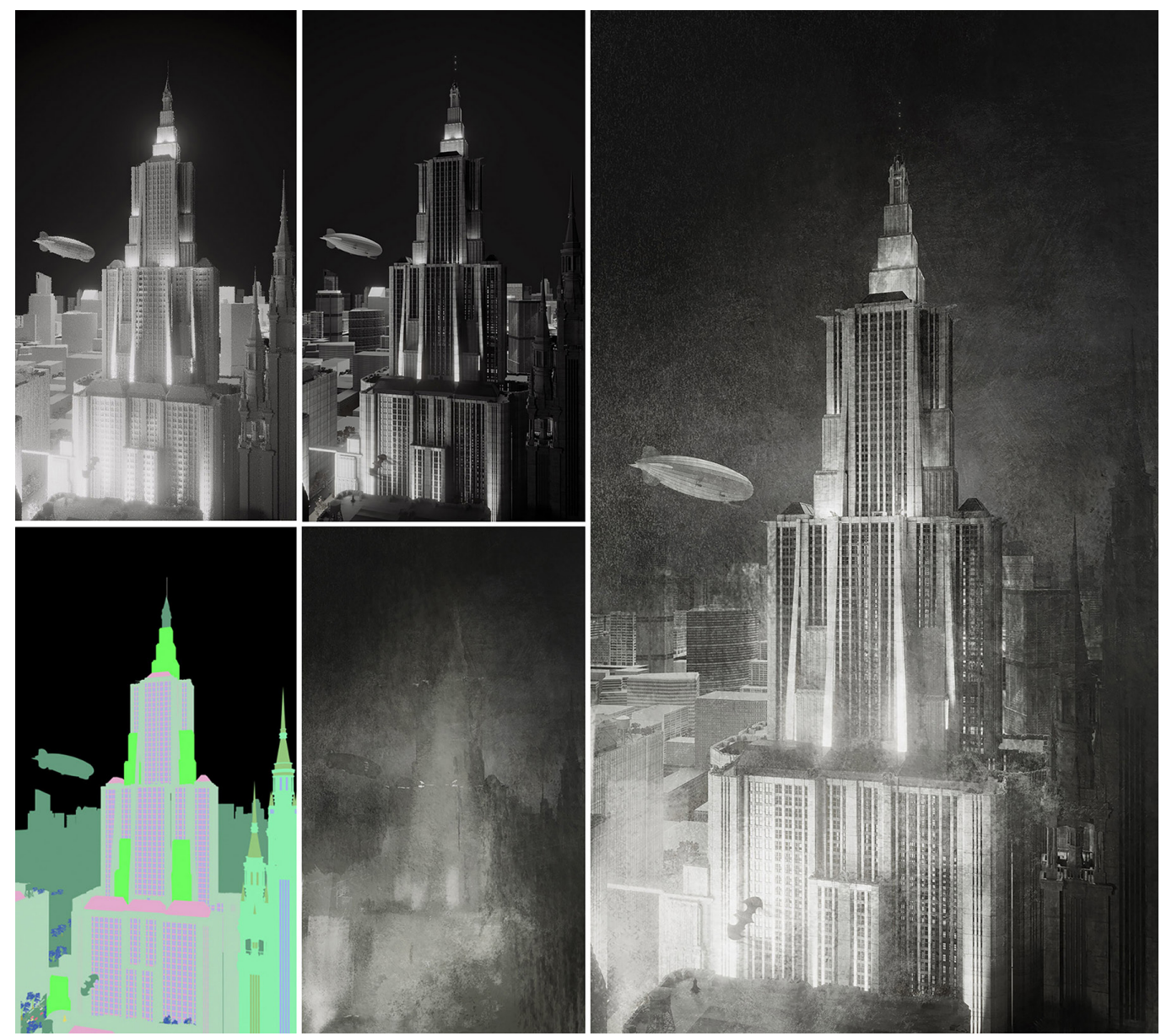
published a few months after Furst's tragic suicide and represents the last work drawn by the English author. In the pages of the Batman book, we can trace all the stylistic elements that connect the universe of Furst to the drawings of Ferriss, for the use of the dark colors and neo-gothic style of its environments, as well as the proximity and references to the engraving and to the most famous scenarios of Piranesian derivation.

\section{On graphic language}

For the reading and interpretation of the drawings of Hugh Ferrres, we can consider the words of Franco Purini, who shares with the American illustrator the role of prospectivist. The Roman architect has, in fact, began to work in the sixties in the study of Maurizio Sacripanti [6], precisely for the ability to draw complex architecture and its spatiality, as in the case of the perspective for the innovative project of the Osaka Pavilion (Expo 1970). It is in a study entitled The Drawing in Italian Architecture that Purini, with the aim of identifying the relationships between architecture and its representation, describes the design as a sort of "infinite palinsesto", which -in a more or less explicit way- conveys "narrative elements, iconic suggestions, diversions, symbolic and allegorical elements" [Purini 20l I, p. 3I]. The author emphasizes how the architectural project's representation goes far beyond the transcription of an idea and its communication; It stratifies memories, reasoning, pentiments, and traces indecisions, arrests, and new starting points in the project process. In this sense, the

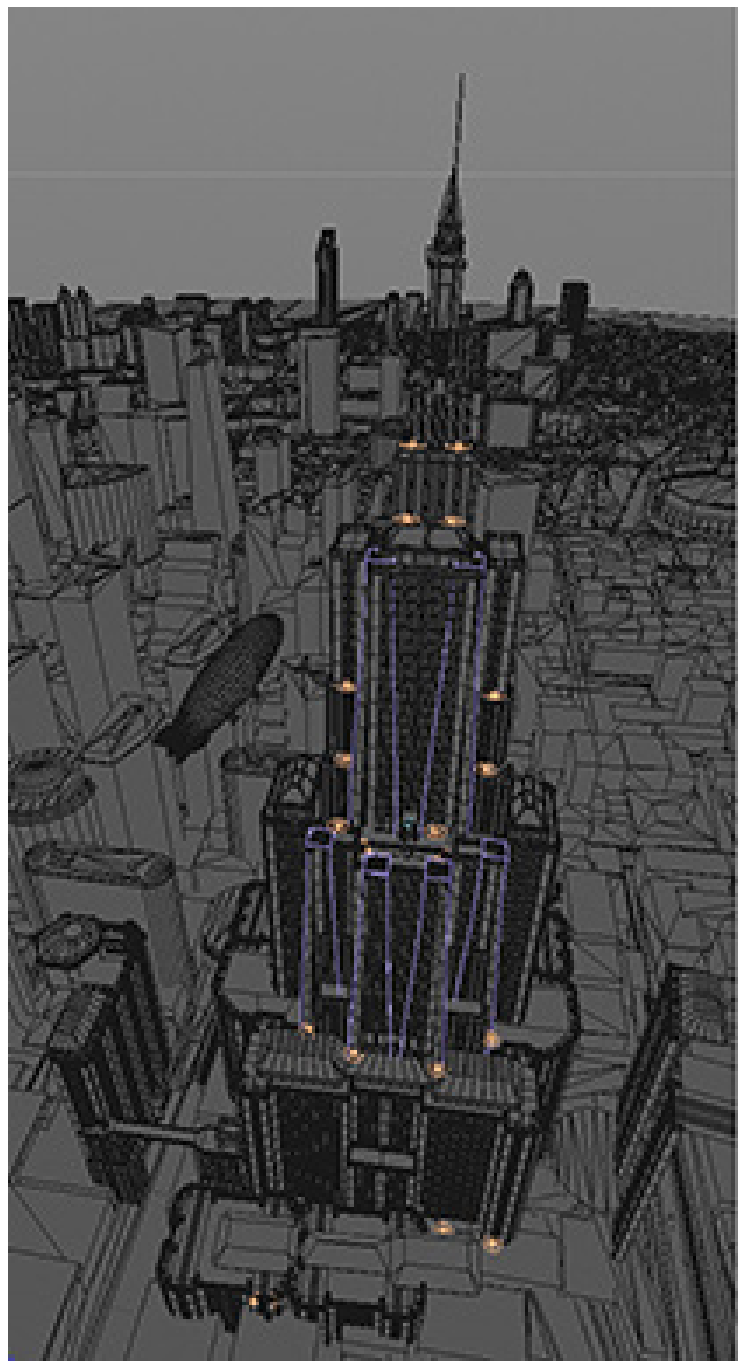


representation, according to the Roman scholar, collects at least three types of content: in the first place, it is the "transcription of an idea", therefore a system of signs able to explicit a thought; The second content refers to the "communication" of the concept itself, it is consequently graphic processing capable of referring to different interlocutors from the author himself. Finally, the design incorporates "memory" or preserves trace of pentiments and allows to go backward in the phases that characterize the design process. In other words, the design is never unique, and Francesco Cellini, in an essay entitled On Talent and Gesture, highlights a further aspect concerning the technique. Referring to the drawing and, more generally, to the work of art, Cellini observes as:

"Very often [...] you can dwell on analyzing only some of its qualities, those commonly considered higher and significant and, so worthy of being discussed and transmitted: we can talk and read about the general structure, the space or form, composition, subjects (if there are), content [...]. However, still remains an embarrassed silence on all the whole of the most minute characteristics, and therefore essential, of a work: on the particular drawing or material quality of the brushstrokes, on the conformation of those signs or traits, [...] on that way of moving that specific brush, or pencil" [Cellini 2006, p. 93].

Cellini poses the attention to the language and on the graphic style to specify the difference between the obsessive, repetitive, and surgically precision of Franco Purini and the robust and synthetic drawing, by Alessandro Anselmi. These differences seem to be attributable at the randomness or to each one's specific talent but, instead, are deeply connected to the designers' choices, to the instruments adopted, and to the expressive result that each designer wants to reach.

Fig. 5. Preparatory sketches in charcoal and graphite for the following phase of digital painting and post-production of the rendering output.

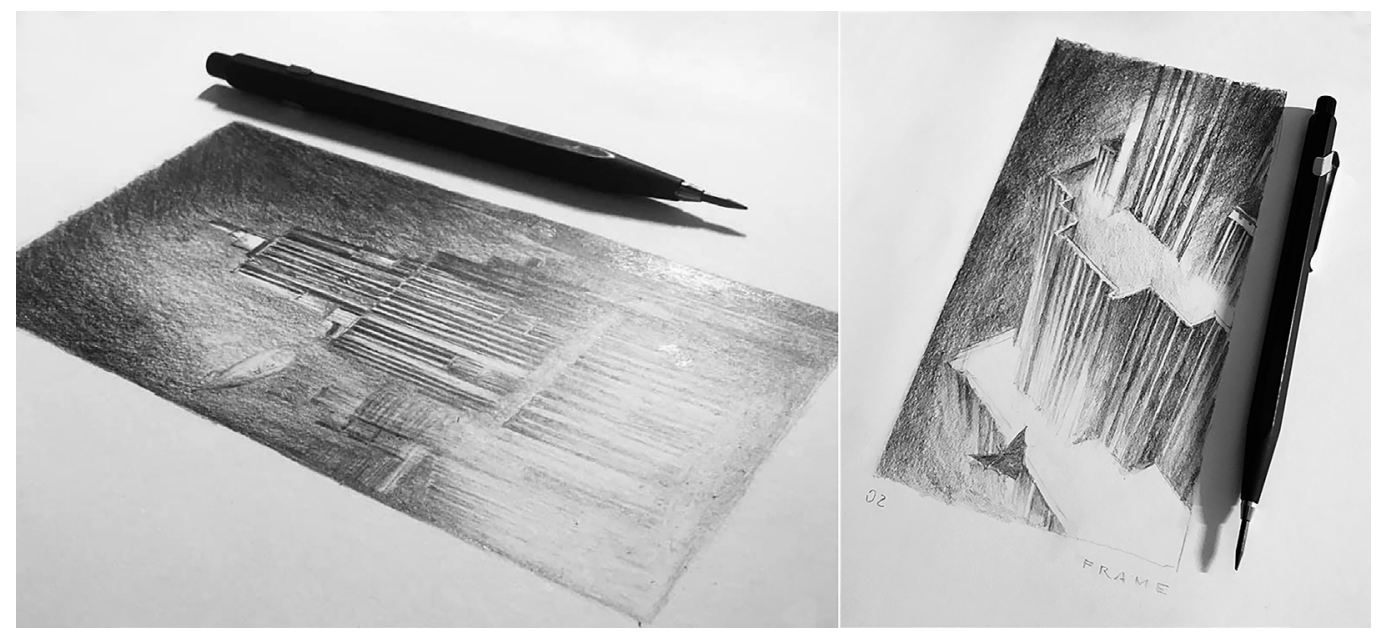

\section{The reiteration of Hugh Ferriss techniques through digital chiaroscuro}

Following Francesco Cellini's reasoning, Hugh Ferriss's drawings and his projects explored the city's vertical development, recording a variety of aspects relating to the technique. Firstly, of a practical nature, related to the charcoal and fusaggine drawing which define a working methodology for representing buildings. Ferriss makes evident the phases ranging from the construction of perspective till the chiaroscuro and of definition of details (fig. 2). Similarly, the images produced by means of the computer for D2 Challenge were processed using distinct phases (fig. 3). For those who write, the challenge was to achieve an expressive content entirely in line with the materiality of traditional design tools, such as the charcoal, used by Ferriss. 
Proceeding by order and comparing Ferriss drawings with the digital development (figs. 2, 3), the first step is linked to the construction of perspective; The point of view is identified through a sketched hand-drawing and through clay rendering in the digital version. The night setting and scenographic lighting, from the bottom upwards, have been reproduced through the anthracite-colored physical sky's contribution and the accent lights at the base of the facade pilasters (fig. 4). The scene lighting project was investigated through rapid charcoal sketches and graphite (fig. 5), which guided the digital and post-production phase of the render outputs.

Following the export of the materials' ID channel, through which you can trace and select all the surfaces, three types of digital brushes corresponding to three levels of brightness and tonal variation were created (fig. 6). The first to simulate the graphite (fig. 6 -a), then used to carry out surface textures on the clearest parts of the image; the second (fig. 6-b) to characterize the intermediate tone of the elaborate. Finally, the third brush (fig. 6-c), used to reproduce both charcoal that fusaggine (in black) and the chalk (in white), to contrast and give depth to the image. The degree of randomness obtained from the combination of pressure and inclination of the brushes on the basic rendering (fig. 7a), and the stratification of the signs in digital painting (fig. 7b), allowed to conceal the homogeneous and intangible nature of the images made in computer graphics, to bring back representation towards a material and imperfect synthesis (fig. 7c), typical of hand drawing and graphite on paper sheet.

Fig. 6. The textures used to post-produce the render output. The three types of digital brushes were created in Adobe Photoshop to match three brightness and tonal variation levels The first brush (A) simulates graphite for the lighter textures of the imat the textures of the image; the intern (B) is used for the intermediate tones and to give a pictorial aspect to the elaboration; the third brush (C) is used to reproduce the charcoal strokes and the fusaggine (dark parts), and the chalk (in white)

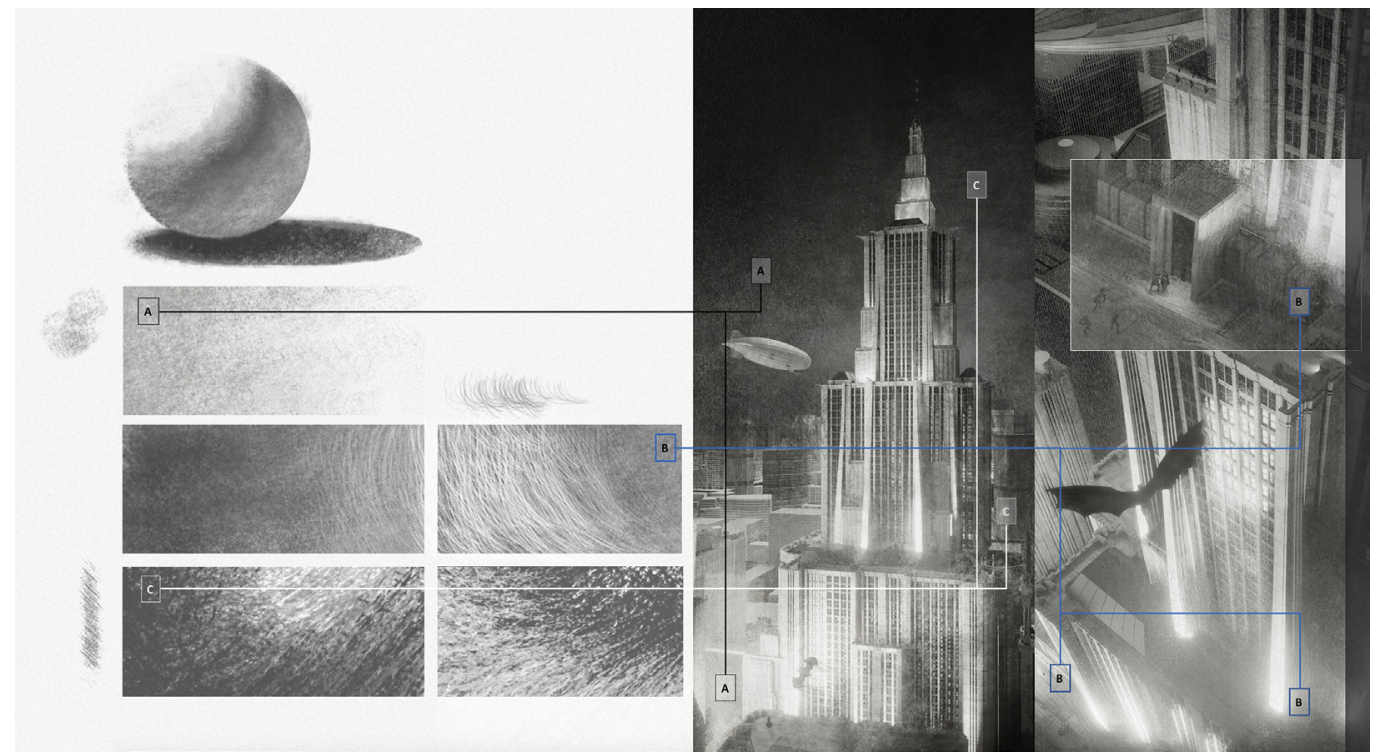

\section{Conclusions}

The competition organized and promoted by the D2 Conference has given way to the architectural visualizers and to the international community of digital artists to analyze and reinterpret the work of Hugh Ferriss, famous American delineator, and visionary designer. In the views presented by the participants emerges as there is no boundary between design and visual development. Mike Golden, for example, explores the architectural project in his spatiality through interactive rendering sessions, in which he studies the behavior of light, materials and, consequently, chooses to change morphology through an iterative process. Furthermore, the graphic language adopted by the authors of this text and of the case presented focuses on the expressive and material yield of traditional drawing techniques 
(such as charcoal and fusaggine) to recall the experiential memory of contact between brushstrokes and the Surfaces. To return to the aforementioned Cellini, a representation is characterized by the conformation of the signs and traits and the compositional aspects, decisively from the project's space and form.

Finally, in a typical manner, all competition participants have investigated the state of art, references, and stimuli from cinema and adopted a visual language consistent with the subject represented. This work methodology is a principle valid for the perspective representation of the spaces, whether and stretches of chiaroscuro by hand, whether they use the most recent rendering solutions available today. In this perspective, the work of the archviz artist, through the expressive possibilities of computer graphics, is increasingly decisive -and in continuity with the role of traditional perspectivist- in rediscovering and investigating both the past architectures and in communicating those of recent development.

Fig. 7. In succession from left to right: the rende output, the overpainting work with digital brushes, the union of the two previous contributions in the synthesis paper.
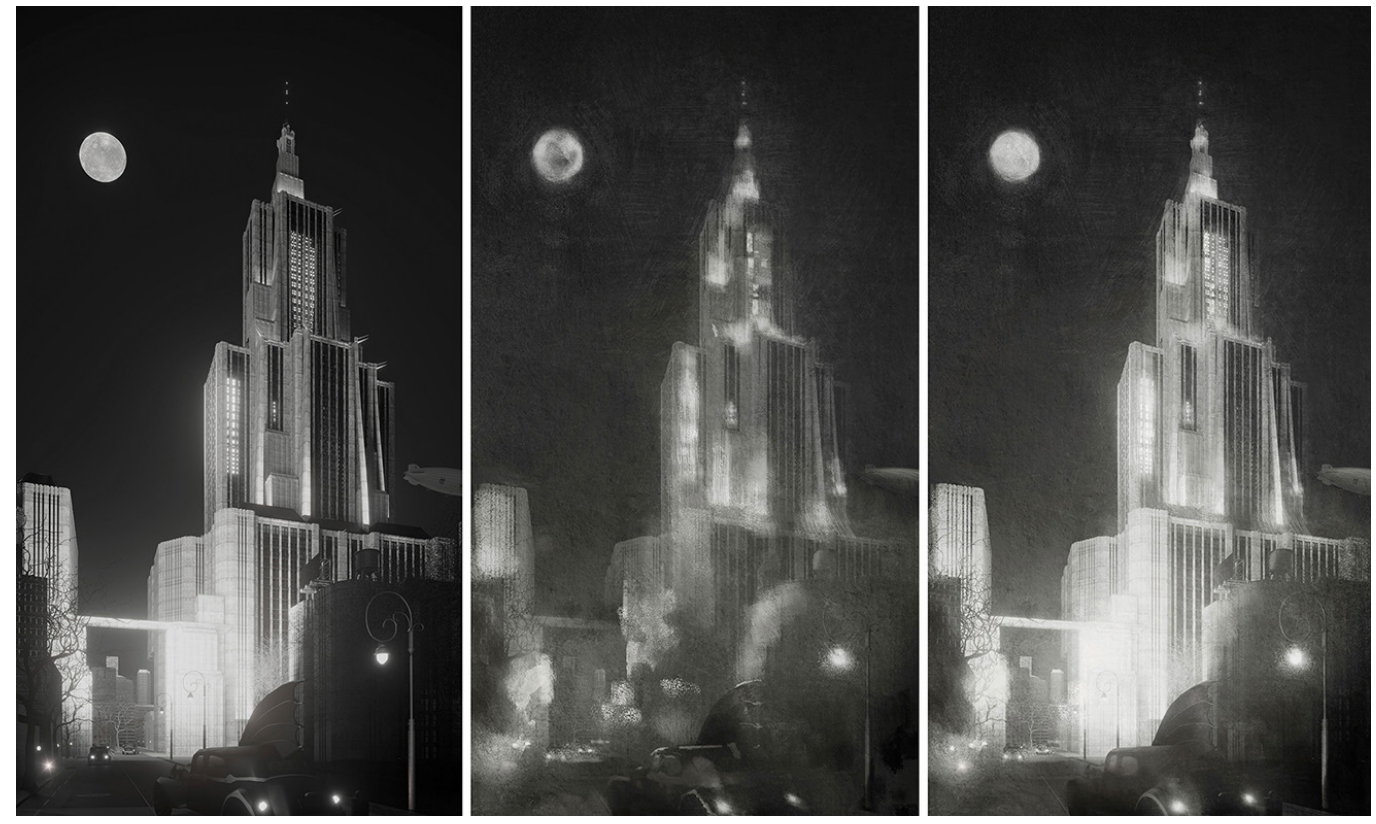

\section{Credits}

The authors worked in the full sharing of the project development here presented and described as case study. In particular Cristian Farinella dealt with the two paragraphs dedicated to Hugh Ferriss's figure and the D2 Challenge. While Lorena Greco has investigated the two sections dedicated to the graphic language and Hugh Ferris techniques' reiteration through digital chiaroscuro.e.

\section{Notes}

[I] The annual conference organized by Bürowhat and specifically by co-founders: Jason Bergeron, Christian Kobierski, and Fabio Palvelli. The intent is to bring together the International Community of Archviz in Vienna and monitor innovations and trends in architectural communication language. The first edition dates back to 2014; For further information, see the D2 Conference site in Vienna: <http://vienna.d2conferences.com> (accessed 2021, Febraury I5).

[2] See: Biraghi M., Ferlenga A. (2012), p. 878.

[3] See: Ferriss H. (1929), pp. |46-149.

[4] The images of the first 25 classifieds are available at the following link: <https://vienna.d2conferences.com/d2challenge/ hugh-ferriss-droquis/hugh-ferriss-droquis-top-25/> (accessed 2021, Febraury 15)

[5] The launch video of the D2 Challenge can be consulted at this link: <https://www.youtube.com/watch?v=r.pl5_lilRU> (accessed 2021, Febraury 15).

[6] The interview of Franco Purini can be consulted at the site: $<$ https://www.youtube.com/watch? $v=$ NoX7t7asAsA $>$ (accessed 2021, Febraury 15). 


\section{References}

Biraghi M., Ferlenga A. (2012). Architettura del Novecento, vol. I. Torino: Einaudi.

Cellini F. (2006). Sul talento e sul gesto. In R. M. Strollo (a cura di). Disegno e conoscenza. Contributi per la storia e l'architettura. Roma: Aracne, pp. 93-104.

Ferriss H. (1929). Rendering, Architectural. In The Encyclopaedia Britannica, I $4^{\text {th }}$ edition. London and New York: University of Chicago Press.

Purini F. (20 I I). II disegno nell'architettura italiana. In M. Petreschi. Diario per segni. Roma: «L'Erma» di Bretschneider, pp. I 75- I83.

\section{Website}

Atelier Crilo (2020). Architectural illustration. <http://www.ateliercrilo.com/architectural-illustration-drawing-watercolors-digitalpainting $>$ (accessed 202 I, February I5)

D2 Conferenze (2020). D2 Vienna 2020. <https://vienna.d2conferences.com> (accessed 202I, February I5).

D2 Vienna (2020). Hugh Ferriss + Droquis, D2 Challenge No. I. <https://vienna.d2conferences.com/d2challenge/hugh-ferriss-droquis/> (accessed 2021, February I5).

D2Vienna (2020). Top 25. <https://vienna.d2conferences.com/d2challenge/hugh-ferriss-droquis/hugh-ferriss-droquis-top-25/> (accessed 2021, February 15).

Droquis (2020). How to make a Hugh Ferriss inspired image in 3D - D2 Render Challenge. <https://www.youtube.com/ watch?v=r.jpl5_lilRU> (accessed 202I, February I5).

Golden M. Artstation - Droquis. <https://www.artstation.com/droquis> (accessed 2021, February I5)

Ferriss H. (1929). The Metropolis of Tomorrow. New York: Ives Washburn. Disponibile al link: <https://bibliodarq.files.wordpress. com/2017/06/ferriss-h-the-metropolis-of-tomorrow.pdf> (accessed 2021, February I5)

Purini F. (20I5). Fondo Sacripanti | Testimonianze | Franco Purini. <https://www.youtube.com/watch?v=NoX7t7asAsA > (accessed 2021, February 15).

Authors
Cristian Farinella, Sapienza Università di Roma, cristian.farinella@uniroma l.it

Lorena Greco, Sapienza Università di Roma, lorena.greco@uniroma l.it

To cite this chapter. Farinella Cristian, Greco Lorena (2021). Il linguaggio grafico di Hugh Ferriss tra chiaroscuro e illustrazione 3D In A/The graphic language of Hugh Ferriss between chiaroscuro and 3D illustration. In Arena A. Arena M. Mediati D. Raffa P. (a cura di). Connettere. Un disegno per annodare e tessere Linguggoi Distanze Tecnologie Atti del $42^{\circ}$ Convegno Internazionale dei Docenti delle Discipline dello Rappresentazione/Connecting. Drawing to weaving relationship. Languages Distances Technologies. Proceedings of the $42^{\text {th }}$ International Conference of Representation Disciplines Teachers. Milano: FrancoAngeli, pp. $722-739$ 